W. Craig • D. Gargano • N. Scotti • T. T. Nguyen •

N. T. Lao $~$ T. A. Kavanagh $\cdot$ P. J. Dix · T. Cardi

\title{
Direct gene transfer in potato: A comparison of particle bombardment of leaf explants and PEG-mediated transformation of protoplasts
}

Received: 28 January 2005 / Revised: 26 April 2005 / Accepted: 15 May 2005 / Published online: 14 September 2005

(C) Springer-Verlag 2005

\begin{abstract}
Direct gene transfer methods in potato would facilitate the transfer of multiple genes and the manipulation of metabolic pathways in this species. In this study, up to 1.8 transformation events per shot $(=0.5$ per bombarded leaf) and 67.2 events per million protoplasts treated were obtained with particle bombardment and PEG-mediated direct DNA uptake, respectively. Limited disassociation of both HPT and GUS genes appeared to occur during the process of integration in only $19 \%$ of transformants. A large number of transformed potato plants with transgene expression at levels comparable to Agrobacterium-mediated transformation was obtained. High levels of GUS expression were only obtained in lines derived from PEG treatment. No correlation between the number of gene insertions and gene expression levels was found, suggesting that multiple insertions may have little or no effect on transgene expression.
\end{abstract}

Keywords Direct gene transfer - Nuclear transformation . Particle bombardment $\cdot$ Potato $\cdot$ Protoplasts

\footnotetext{
Communicated by D. Dudits

W. Craig and D. Gargano contributed equally to this work

W. Craig · D. Gargano · N. Scotti · T. Cardi $(\bowtie)$

CNR-IGV, Institute of Plant Genetics, Res. Div. Portici,

via Università 133 ,

80055 Portici (NA), Italy

e-mail: cardi@unina.it

Tel.: +39-081-2539223

Fax: +39-081-7753579

T. T. Nguyen · P. J. Dix

Plant Cell Biology Laboratory, Biology Department, National University of Ireland-Maynooth,

Maynooth, Co. Kildare, Ireland

N. T. Lao · T. A. Kavanagh

Plant Molecular Biology Laboratory, Smurfit Institute of

Genetics, Trinity College,

Lincoln Place Gate, Dublin 2, Ireland
}

\section{Introduction}

Genetic transformation has become an established technology for the improvement of crop plants. Central to this technology has been the ability to incorporate agronomically important genes into the nuclear genome. A number of papers have reported the transfer of genes into potato nuclei and the subsequent regeneration of transgenic plants, with the almost exclusive use of Agrobacterium spp. to mediate the transformation. Of late, fresh interest in plant transformation has derived from proposals to use plants as "bio-factories", for the manipulation of metabolic pathways for improved nutrition (e.g. vitamins) or processing (complex carbohydrates, lignins). Many of these applications require, or would benefit from, a capacity for the introduction of multiple genes either to the nucleus or to plastids. Agrobacterium-mediated delivery, however, is not favourable in the former case and is not even possible in the latter. Using the biolistic approach, reports are beginning to emerge on the possibility of plastid transformation in potato (Sidorov et al. 1999; Gargano et al. 2003; Nguyen et al. 2005). The transfer of multiple traits to the nucleus through (co-)bombardment of plasmids and/or gene cassettes has been demonstrated in rice and other species (Chen et al. 1998; Fu et al. 2000), with some cases also excluding redundant vector backbone DNA.

Although the successful uses of particle bombardment (Romano et al. 2001, 2003; Nguyen et al. 2002) and PEGmediated DNA uptake in protoplasts (Fehér et al. 1991) to produce transgenic potato have been described, either they used obscure breeding lines or their efficiencies were rather low. The present study was undertaken to establish DNA uptake protocols in potato based on both methodologies, and to analyse the integration and expression of transgenes in plants obtained by the two procedures. The development of reliable and efficient nuclear transformation procedures is reported using both approaches, paving the way for potato's role in molecular farming. Both procedures make use of the widely grown potato cv. Désirée and result in higher efficiencies than previously reported 
by using a combination of enhanced DNA uptake parameters, hygromycin selection and different regeneration media. The integration pattern of transgenes was investigated by PCR and Southern analyses, whereas their expression was studied by northern analysis alongside histochemical and fluorimetric $G U S$ assays. Transgene expression varied widely among individual regenerants while a significant effect of the transformation procedure on the expression of the unselected transgene was also evident.

\section{Materials and methods}

Gene constructs and plant material

The nuclear transformation vector pGUS-HYG was based on the vector pUC19 (Sambrook and Russell 2001); it contains the reporter gene encoding $\beta$-glucuronidase $(G U S)$ and a selectable marker gene encoding hygromycin phosphotransferase (HPT), driven by CaMV $35 \mathrm{~S}$ and nopaline synthase promoters, respectively (Fig. 1).

In vitro-grown Solanum tuberosum cv. Désirée shoots were used as a source of 4-6 week-old leaves for both particle bombardment and protoplast direct DNA uptake experiments. Stock plants were grown on basal medium containing MS salts (Murashige and Skoog 1962), B5 vitamins (Gamborg et al. 1968), $30 \mathrm{~g} \mathrm{l}^{-1}$ sucrose and $8 \mathrm{~g} \mathrm{l}^{-1}$ agar (MS/B530 medium), and cultured at $20^{\circ} \mathrm{C}$ with a $16 \mathrm{~h}$ photoperiod of $50-70 \mu \mathrm{E} \mathrm{m}^{-2} \mathrm{~s}^{-1}$ (daylight fluorescent tubes).

\section{Plant transformation}

As far as the biolistic approach was concerned, a mean of 3-4 potato leaflets per $6 \mathrm{~cm}$ Petri dish (covering an approximate area of 9-10 $\mathrm{cm}^{2}$ ) were placed on MS/B530 medium containing $2.0 \mathrm{mg} \mathrm{l}^{-1}$ 2,4-D and $0.8 \mathrm{mg} \mathrm{l}^{-1}$ zeatin riboside (M6 medium; Yadav and Sticklen 1995), and supplemented with $0.2 \mathrm{M}$ mannitol. For protocol one, these explants were bombarded immediately after being placed on the above medium, whereas for protocol two, explants were left on the medium for $24 \mathrm{~h}$ prior to bombardment. The coating of gold

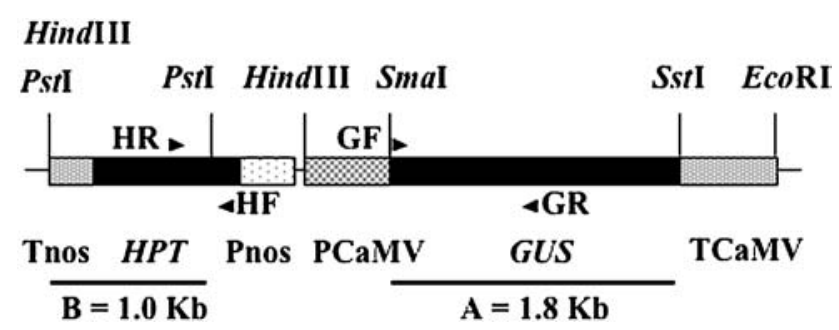

Fig. 1 Genetic map of the insert of nuclear $\mathrm{p} G U S-\mathrm{HYG}$ transformation vector. Pnos, Tnos: nopaline synthase promoter and terminator; GUS: B-glucuronidase gene; PCaMV, TCaMV: CaMV35S promoter and terminator; HPT: hygromycin phosphotransferase gene. HF and HR: HPT forward and reverse primer annealing positions; GF and GR: GUS forward and reverse primer annealing positions. A: probe for the GUS gene; B: probe for the HPT gene particles $(0.6 \mu \mathrm{m})$ with DNA was undertaken using the protocol of Maliga (1995) with minor modifications, and particle bombardment was carried out using a PDS-1000/He device (Bio-Rad Laboratories, Inc.). Particles were fired at a pressure of $1,100 \mathrm{psi}$, and at either 6 or $9 \mathrm{~cm}$ distance from explants. Two days after bombardment, the leaflets were dissected into approximately $25 \mathrm{~mm}^{2}$ pieces and transferred onto fresh M6 medium without mannitol and containing $10 \mathrm{mg} \mathrm{l}^{-1}$ hygromycin B. They were then either cultured continuously under the same light and temperature conditions as for stock plants until shoots developed (protocol one), or transferred 4 weeks post-bombardment to MS/B530 medium containing $2.0 \mathrm{mg} \mathrm{l}^{-1}$ gibberellic acid and $0.8 \mathrm{mg} \mathrm{l}^{-1}$ zeatin riboside ( $\mathrm{R} 4$ medium; Yadav and Sticklen 1995; protocol two) and cultured as before but with $15 \mathrm{mg}^{-1}$ hygromycin until shoots developed. Regenerated shoots were excised from explants and transferred individually onto MS/B530 medium with $15 \mathrm{mg} \mathrm{l}^{-1}$ hygromycin.

For PEG-mediated transformation, leaf protoplasts were isolated according to Cardi et al. (1990) with minor modifications. Harvested leaves were conditioned in medium 'Con' (Haberlach et al. 1985) at $4{ }^{\circ} \mathrm{C}$ for $24 \mathrm{~h}$ prior to enzymatic digestion and cellulase 'Onozuka' RS (Yakult Pharmaceutical Ind. Co. Ltd., Japan) was used instead of cellulase R-10. Purified protoplasts were washed in $190 \mathrm{mM}$ mannitol, $100 \mathrm{mM} \mathrm{CaCl}_{2}, 0.5 \%$ MES, pH 5.6 (Fehér et al. 1991). They were then resuspended at $1.6 \times$ $10^{6}$ protoplasts $\mathrm{ml}^{-1}$ in $0.5 \mathrm{M}$ mannitol, $15 \mathrm{mM} \mathrm{MgCl}_{2}$, $0.1 \%$ MES, pH 5.6 (Negrutiu et al. 1987). Following a protocol modified from the same report, carrier salmon sperm DNA (Invitrogen) and plasmid DNA were added (each at a final concentration of $50 \mu \mathrm{g} \mathrm{ml}^{-1}$ ) to $100 \mu \mathrm{l}$ protoplast suspension per tube. Subsequently, the same volume of either 25 or $40 \%$ PEG 4000 was gently added and the mixture was incubated for 15 or $5 \mathrm{~min}$, respectively. After incubation with PEG, the protoplasts were washed once more, prior to culturing. Protoplast culture was carried out in alginate gel (Vieira et al. 1990), with a modified version of the initial culture medium of Cardi et al. (1990), exchanging $0.1 \mathrm{mg}^{-1} \mathrm{NAA}$ and $0.5 \mathrm{mg} \mathrm{l}^{-1}$ zeatin for $1 \mathrm{mg} \mathrm{l}^{-1} \mathrm{NAA}$ and $0.4 \mathrm{mg} \mathrm{l}^{-1}$ BAP. After 2 weeks, this was followed sequentially by liquid versions of media "Cul" and "Dif" (Haberlach et al. 1985) at 4-6 week culture intervals, before finally culturing isolated protoplast-derived calli (pcalli) on the surface of solid shoot regeneration medium (Sidorov et al. 1999; "Mon"). Antibiotic selection commenced 2 weeks post-transformation with the application of $5 \mathrm{mg} \mathrm{l}^{-1}$ hygromycin, which was then increased to 10 and $15 \mathrm{mg} \mathrm{l}^{-1}$ following a further 1 and 2 weeks of culture. Although multiple shoots formed from each pcallus growing in selection medium, only 1 shoot per pcallus was excised and transferred individually onto MS/B530 medium with $15 \mathrm{mg} \mathrm{l}^{-1}$ hygromycin.

Rooted shoots were then transferred to soil in a growth chamber, with a day/night temperature of $25 / 20^{\circ} \mathrm{C}, 70 \%$ humidity, and a $14 \mathrm{~h}$ photoperiod at $300 \mu \mathrm{E} \mathrm{m}^{-2} \mathrm{~s}^{-1}$. 
GUS enzyme assays

Detection of GUS activity in 4 week-old regenerants (histochemical assay) and 5 weeks post-propagation in vitro shoots (fluorimetric assay) was carried out as described (Jefferson et al. 1987), using 5-bromo-4-chloro-3-indolyl$\beta$-D-glucuronic acid (X-GlcA; Duchefa) with a stereomicroscope, and 4-methylyumbelliferyl- $\beta$-D-glucuronide (4-MUG) with a Bio-Rad VersaFluor ${ }^{\mathrm{TM}}$ fluorometer, respectively. Soluble protein contents were determined using the Bio-Rad Protein Assay Kit.

\section{Molecular analyses}

For PCR analysis, DNA was extracted from fresh leaf tissue $(100 \mathrm{mg})$ of regenerated shoots, using a DNeasy Plant Mini Kit (Qiagen), following manufacturer's instructions. Purified DNA was tested for the presence of GUS and $H P T$ with the following primer pairs, respectively: GUS forward 5'-CCTGTAGAAACCCCAACCCGTG-3', reverse 5'-CCCGGCAATAACATACGGCGTG-3', product size $365 \mathrm{bp}$; HPT forward 5'-AGCTGCGCCGATGGTTT CTACAA- $3^{\prime}$, reverse 5'-ATCGCCTCGCTCCAGTCAA TG-3', product size 508 bp (G. Nugent, personal communication). DNA (50-75 ng) was amplified according to manufacturer's instructions (Perkin Elmer). The reaction conditions for amplification of the individual genes were as follows: denaturation at $94^{\circ} \mathrm{C}$ for $3 \mathrm{~min}$, then 30 cycles $\left(94^{\circ} \mathrm{C}, 30 \mathrm{sec} ; 56^{\circ} \mathrm{C}, 45 \mathrm{sec} ; 72^{\circ} \mathrm{C}, 1 \mathrm{~min}\right)$ followed by $10 \mathrm{~min}$ final extension at $72^{\circ} \mathrm{C}$; while for the combined genes the reaction conditions were: denaturation at $94^{\circ} \mathrm{C}$ for $3 \mathrm{~min}$, then 30 cycles $\left(94^{\circ} \mathrm{C}, 30 \mathrm{sec} ; 58^{\circ} \mathrm{C}, 1 \mathrm{~min} ; 72^{\circ} \mathrm{C}\right.$, $2 \mathrm{~min} 30 \mathrm{sec}$ ) followed by $10 \mathrm{~min}$ final extension at $72^{\circ} \mathrm{C}$.

For Southern analysis, 8-12 $\mu \mathrm{g}$ of leaf genomic DNA, isolated as previously reported (Cardi et al. 1999), were digested with EcoRI or EcoRI/HindIII, electrophoresed in $1 \times \mathrm{TBE}$ agarose gel and blotted onto Hybond- $\mathrm{N}^{+}$ membrane (Amersham) under alkaline conditions $(0.4 \mathrm{~N}$ $\mathrm{NaOH}$ ). Radioactively-labelled probes (HPT and GUS genes) were generated by random priming (Takara Ltd.) and subsequent hybridisations were carried out under high stringency conditions with $40 \%$ formamide. The blots were then washed one to three times at $42^{\circ} \mathrm{C}(10 \mathrm{~min}$ each wash) with $0.1 \times \mathrm{SSC}, 0.1 \% \mathrm{SDS}$ as final wash before autoradiography.

Total cellular RNA was extracted from leaves of growth chamber-grown plants using the guanidine thiocyanate method of Chomeczynski and Sacchi (1987). RNA $(20 \mu \mathrm{g})$ was electrophoresed in a $1 \times$ MOPS agarose/formaldehyde gel $(1.2 \% \mathrm{w} / \mathrm{v})$, and transferred with $20 \times \mathrm{SSC}$ onto Hybond- $\mathrm{N}^{+}$membrane. RNA gel blot hybridisation was carried out as reported for DNA blot, as were washes and analyses. The quantification of transgene mRNA and total rRNA bands was carried out on digital scans of the relevant blots and gels using the ImageQuant program (Amersham). The relative expression value (RV) for each transcript was calibrated to account for the variation in their respective
rRNA levels, and then calculated as a percentage of the strongest expressor, line A1-21 $(\mathrm{RV}=100)$.

\section{Statistical analyses}

Notched box plots (McGill et al. 1978) were graphed to visualise the distribution of GUS expression levels from 4-MUG-based fluorimetric analyses of transformants derived from the two different transformation procedures. A $\mathrm{K}$-mean analysis was then carried out to divide the GUS expression levels of all transformants into three different clusters $(P<0.01)$ : Low, Medium, and High. Representative lines from each cluster were then chosen to undergo DNA and RNA gel blot analyses. All statistical analyses were carried out using the SYSTAT computer program package (SYSTAT Inc., USA).

\section{Results}

Regeneration of transgenic shoots

Transformed potato plants were successfully obtained using both methods investigated. For particle bombardment, best results were obtained with a double-step regeneration protocol following a $24 \mathrm{~h}$ preculture phase prior to bombardment. After 4 weeks of culture on hygromycincontaining (hyg ${ }^{+}$) M6 medium, green calli were evident on approximately $20 \%$ of explants. Following a further 4-6 weeks of culture on hyg ${ }^{+} \mathrm{R} 4$ medium, a minimum of 2 shoots could be harvested from each regenerating callus for rooting under continued hygromycin selection. Care was taken to excise shoots from disparate sites of each explant; nevertheless, only those regenerated from independent explants were considered for the calculation of transformation efficiency and (in most cases) for subsequent statistical and molecular analyses. Thus, 0.5 and 1.8 hyg $^{\mathrm{r}}$ shoots per shot, corresponding to 0.1 and 0.5 shoots per bombarded leaf, were produced with the one-step and double-step protocols, respectively (Table 1).

Using the protocol for direct uptake to protoplasts, green hyg ${ }^{\mathrm{r}}$ pcalli first appeared in "Cul" medium 3-4 weeks after transformation when the selection level was between 10 and $15 \mathrm{mg} \mathrm{l}^{-1}$ hygromycin. Their growth continued on "Dif" medium until finally multiple hyg ${ }^{\mathrm{r}}$ shoots were produced on "Mon" medium, approximately 10-12 weeks after transformation (Fig. 2a). More hyg ${ }^{\mathrm{r}}$ pcalli formed in treatments based on $12.5 \%$ PEG $(0.02 \%$ of original number of protoplasts treated) as compared to $20 \%$ PEG $(0.003 \%)$. These were at least 10-fold lower than the pcallus formation frequency of $0.23 \%$ obtained from non-treated, control protoplasts (Table 2).

Similar proportions of rooted hyg $\mathrm{g}^{\mathrm{r}}$ shoots $(67-68 \%)$ were obtained from the two methods (Tables 1 and 2; Fig 2b). Fifteen $\mathrm{mg}^{-1}$ was shown to be an effective hygromycin selection level as PCR analyses confirmed the presence of the $H P T$ gene in 114 out of 115 transformed plants tested 
Table 1 Production of transgenic potato plants via particle bombardment

\begin{tabular}{|c|c|c|c|c|c|c|c|c|}
\hline \multirow[t]{2}{*}{ Firing distance $(\mathrm{cm})$} & \multirow[t]{2}{*}{ No. of shots ${ }^{a}$} & \multicolumn{2}{|c|}{ No. of explants } & \multicolumn{5}{|c|}{ No. of regenerants ${ }^{c}$} \\
\hline & & cultured & with shoots ${ }^{b}$ & $\mathrm{Hyg}^{\mathrm{r}}$ & X-Glc ${ }^{+}$ & PCR $H P T^{+}$ & PCR $G U S^{+}$ & PCR $(H P T+G U S)^{+}$ \\
\hline \multicolumn{9}{|l|}{$\overline{\text { Protocol } 1^{\mathrm{d}}}$} \\
\hline 6 & 14 & 294 & 10 & $26(41)$ & $23(41)$ & $26(26)$ & $24(26)$ & $2(4)$ \\
\hline 9 & 14 & 327 & 5 & $10(12)$ & $8(12)$ & $8(8)$ & $8(8)$ & $1(1)$ \\
\hline \multicolumn{9}{|l|}{ Protocol 2} \\
\hline 6 & 7 & 188 & 11 & $29(37)$ & $24(36)$ & $15(15)$ & $15(15)$ & $3(4)$ \\
\hline 9 & 7 & 169 & 14 & $25(44)$ & $26(44)$ & $12(12)$ & $10(12)$ & $3(6)$ \\
\hline
\end{tabular}

${ }^{a}$ Mean number of leaves per shot $=3-4$

${ }^{\mathrm{b}}$ More than 1 shoot harvested per regenerating explant

${ }^{\mathrm{c}}$ Number in brackets indicates total number of shoots tested. $\mathrm{Hyg}^{\mathrm{r}}=$ shoots rooting in the presence of 15 mg $1^{-1}$ hygromycin $\mathrm{B}$

${ }^{\mathrm{d}}$ Protocol $1=$ no preculture, single-step regeneration; Protocol $2=24 \mathrm{~h}$ preculture, double-step regeneration; see text for details
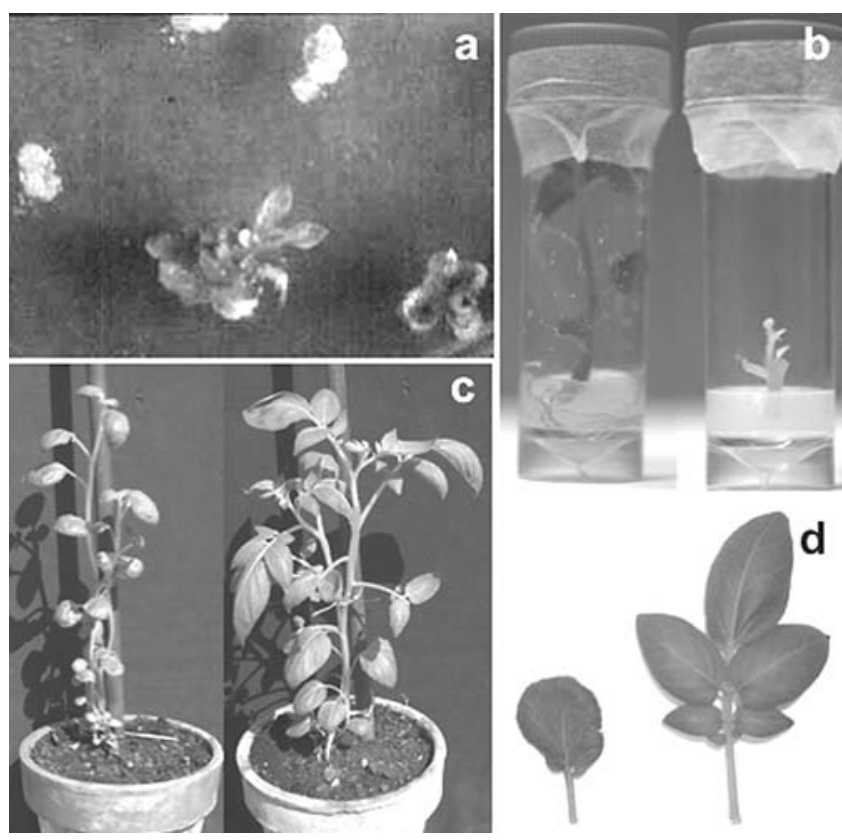

Fig. 2 a Regenerating protoplast-derived calli on selection medium; b Regenerated transgenic (left) and control (right) shoots on $\mathrm{Hyg}^{+}$ rooting medium; c and $\mathbf{d}$ Transgenic potted plants and leaves with abnormal (left) and normal (right) phenotype

(Fig. 3a and b; Tables 1 and 2). Of these 114 transgenics, 94\% were co-transformed with the GUS gene. An additional PCR analysis using the reverse primers of each gene found that 50 out of $62(81 \%) H P T^{+}$transformants tested gave the anticipated $2.5 \mathrm{~kb}$ PCR product (Tables 1 and 2) for transgene cointegration. Eleven transformants did not give any combined PCR product. Seven of them were already known to be negative for GUS, whereas the remaining four, known to be positive for both HPT and GUS fragments alike, probably had the transgenes integrated at differing loci. An exceptional protoplast-derived regenerant gave the anticipated 508 (HPT) and 365 (GUS) bp PCR products, but only a $1.6 \mathrm{~kb}$ fragment for the combined PCR product (Fig. 3c). Taken together, these results indicate that (partial) disassociation of the two genes occurred during the process of integration in 19\% of transformation events examined. However, transgene separation occurred in 6 out of 47 protoplast-derived (PD) lines compared to 6 out of 15 biolistics-derived (BD) lines, suggesting a transformation protocol-derived effect.

Expression and molecular characterisation of transgenic plants

Histochemical GUS analyses exhibited a range of activity levels, from leaves with no or small areas of faint blue colouration, to those with intense solid blue cover (data not shown). No coloured GUS activity areas were observed in any control-derived plants. Overall, approximately two thirds of shoots expressed the co-inserted GUS gene (Tables 1 and 2).

Good correlation between histochemical and fluorimetric GUS expression was demonstrated (data not shown). The biolistics-derived plants showed lower mean (26.9 pmoles $\mathrm{MU} / \mu \mathrm{g}$ protein/min) and median (7.8) GUS expression levels to those of plants derived from protoplasts (200.8 and 50.3, respectively). Although the lower extreme values were approximately equivalent for all populations, the upper extreme value of the PD population (1120.5) was at least 10-fold greater than that of the BD population (109.3), which was, in itself, approximately 10-fold greater than that of the control population (15.7) (Fig. 4). K-mean analysis of GUS expression levels divided the whole transformant population into three distinct $(P<0.01)$ clusters: Low, Medium and High (Table 3). The Low cluster comprised values from both non-expressing or low-expressing $\mathrm{BD}$ and PD lines, whereas the Medium and High clusters comprised only PD values. Unsuccessful attempts were made to statistically disaggregate the Low cluster and separate the non-expressing from the low expressing lines. Hence, for further analyses, within the Low cluster, we decided to choose plants with values close to those of the controls and, in general, to avoid those at the cluster boundaries. The expression levels of the majority of transformants (54 out of 68) fell into the Low cluster, the mean (36.0) of which was not significantly different $(P=0.083)$ from that of the control population. The remaining 14 transformants were divided between the Medium and High clusters, with mean values of both being significantly greater than control levels (327.7 and 935.1, respectively; $P<0.001$ ). 
Table 2 Production of transgenic potato plants via direct DNA uptake to protoplasts (pps)

\begin{tabular}{|c|c|c|c|c|c|c|c|c|}
\hline \multirow[t]{2}{*}{ Treatment $^{\mathrm{a}}$} & \multirow[t]{2}{*}{ No. of pps treated } & \multicolumn{2}{|l|}{ No. of pcalli } & \multicolumn{5}{|c|}{ No. of regenerants ${ }^{\mathrm{c}}$} \\
\hline & & hyg $^{\mathrm{r}}$ (green) & with shoots ${ }^{b}$ & $\mathrm{Hyg}^{\mathrm{r}}$ & $\mathrm{X}-\mathrm{Glc}^{+}$ & PCR $H P T^{+}$ & PCR $G U S^{+}$ & $\mathrm{PCR}(H P T+G U S)^{+}$ \\
\hline \multicolumn{9}{|c|}{$12.5 \% \mathrm{PEG} / 15 \mathrm{~min}$} \\
\hline Exp 1 & $3.2 \times 10^{5}$ & 81 & 42 & $27(42)$ & $22(40)$ & $29(29)$ & $26(29)$ & $23(27)$ \\
\hline $\operatorname{Exp} 2$ & $3.2 \times 10^{5}$ & 44 & 22 & $16(22)$ & $15(22)$ & $16(17)$ & $16(17)$ & $13^{\mathrm{d}}(14)$ \\
\hline \multicolumn{9}{|c|}{$20 \% \mathrm{PEG} / 5 \mathrm{~min}$} \\
\hline Exp 1 & $3.2 \times 10^{5}$ & 13 & 10 & $6(10)$ & $7(9)$ & $5(5)$ & $5(5)$ & $4(4)$ \\
\hline $\operatorname{Exp} 2$ & $3.2 \times 10^{5}$ & 8 & 3 & $3(3)$ & $2(3)$ & $3(3)$ & $3(3)$ & $1(2)$ \\
\hline Control $^{\mathrm{e}}$ & $3.2 \times 10^{5}$ & 0 & - & - & - & - & - & - \\
\hline
\end{tabular}

${ }^{a}$ See text for details

${ }^{\mathrm{b}}$ Only 1 shoot was harvested per regenerating pcallus

${ }^{\mathrm{c}}$ The number in brackets indicates the total number of regenerants tested. $\mathrm{Hyg}^{\mathrm{r}}=$ shoots rooting in the presence of $15 \mathrm{mg} \mathrm{l}^{-1}$ hygromycin $\mathrm{B}$ ${ }^{\mathrm{d}}$ One of these gave an unexpected PCR product of $1.6 \mathrm{~Kb}$

${ }^{\mathrm{e}}$ The equivalent number of non-transformed protoplasts produced 735 regenerating pcalli in the absence of hygromycin selection

Table 3 Summary statistics for clusters derived from K-mean analysis of fluorimetric $G U S$ (MUG) assay results

\begin{tabular}{|c|c|c|c|c|c|c|c|c|}
\hline \multirow[t]{2}{*}{ Cluster $^{\mathrm{a}}$} & \multicolumn{3}{|c|}{ No. of plants } & \multicolumn{5}{|c|}{ pmoles MU/ $\mu \mathrm{g}$ protein/min } \\
\hline & Total & $\mathrm{PD}^{\mathrm{b}}$ & $\mathrm{BD}^{\mathrm{b}}$ & Min & Max & Mean $^{c}$ & SD & Median \\
\hline Control & 8 & - & - & 0.1 & 15.7 & $4.9^{\mathrm{A}}$ & 5.1 & 3.5 \\
\hline Low & 54 & 34 & 20 & 0.2 & 181.7 & $36.0^{\mathrm{A}}$ & 45.0 & 12.0 \\
\hline Medium & 8 & 8 & 0 & 199.1 & 527.7 & $327.7^{\mathrm{B}}$ & 125.2 & 288.0 \\
\hline High & 6 & 6 & 0 & 686.0 & 1120.5 & $935.1^{\mathrm{C}}$ & 190.4 & 960.8 \\
\hline
\end{tabular}

${ }^{\mathrm{a}}$ See text for description of cluster formation ${ }^{\mathrm{b}} \mathrm{PD}$ : protoplast-derived; BD: biolistics-derived

${ }^{\mathrm{c}}$ Means with the same letter are not significantly different at $0.01 \%$ level. To achieve homogeneity of error variances, ANOVA was conducted on square roots of original values
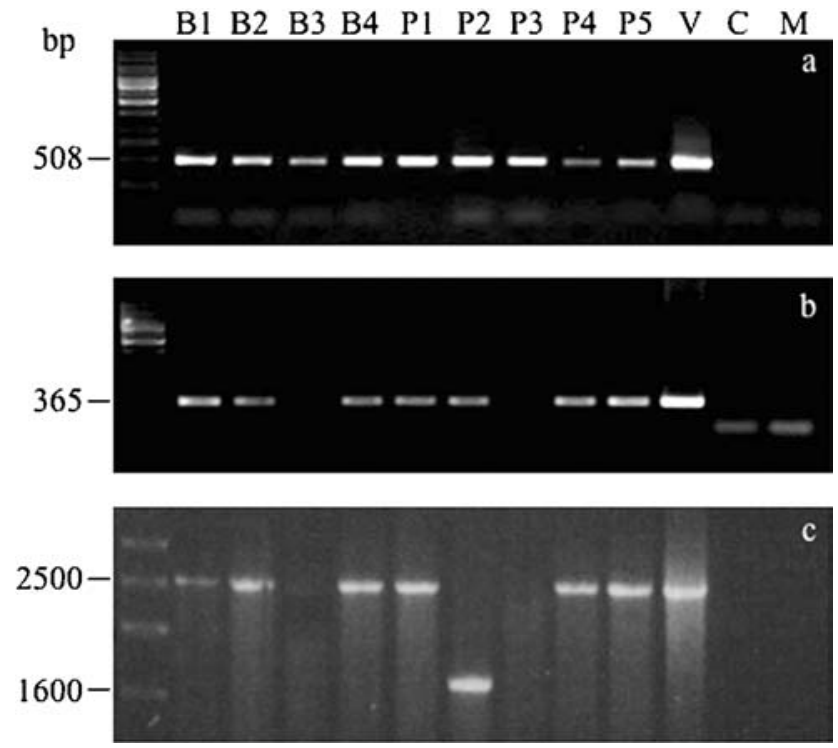

Fig. 3 PCR results of a sample of transformed potato plants screened for both HPT (a) and GUS (b) individual genes, and $H P T+G U S$ (c) combined genes. B1-B4 = biolistics-derived plants; P1-P5 = protoplast-derived plants. From left to right: $\mathrm{B} 1=\mathrm{B} 27-5 \mathrm{E} ; \mathrm{B} 2=$ $\mathrm{B} 34-12 \mathrm{~A}$; $\mathrm{B} 3=\mathrm{B} 34-24 \mathrm{D}$; $\mathrm{B} 4=\mathrm{B} 27-15 \mathrm{~B} ; \mathrm{P} 1=\mathrm{A} 1-21$; $\mathrm{P} 2=\mathrm{A} 2-$ $01 ; \mathrm{P} 3=\mathrm{A} 1-25 ; \mathrm{P} 4=\mathrm{A} 1-17 ; \mathrm{P} 5=\mathrm{A} 1-46 ; \mathrm{V}=\mathrm{p} G U S-\mathrm{HYG}$ control; $\mathrm{C}=$ Désirée control; $\mathrm{M}=$ reaction mix

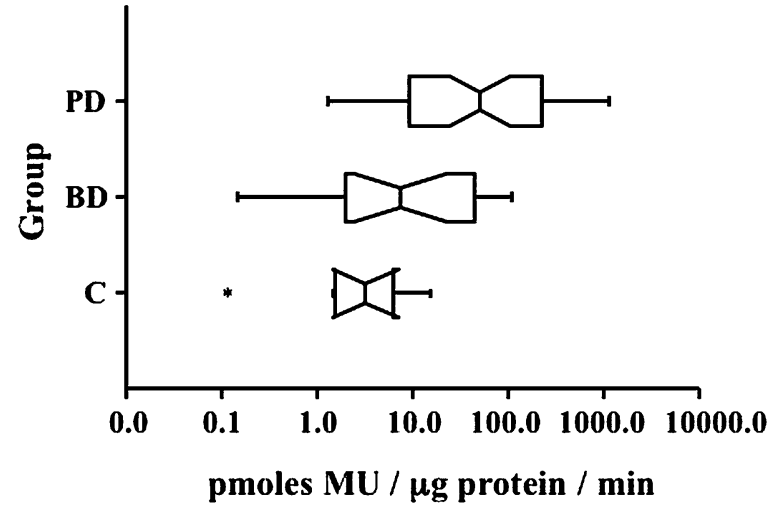

Fig. 4 Notched box plots reporting the expression of the GUS gene as based on fluorimetric MUG assay in protoplast-derived (PD), biolistics-derived (BD) and control plants (C)

The expected $1.8 \mathrm{~kb}$ GUS transcript was observed only in the Medium and High cluster transformants analysed (Fig. 5). Three of the Low category transformants did however express smaller truncated transcripts, but their MU production levels $(2.0,3.3$ and 4.0 pmoles $\mathrm{MU} / \mu \mathrm{g}$ protein/min) were not significantly different to control levels, indicating that the transcripts did not result in functional GUS expression. Calculated RV levels compared 


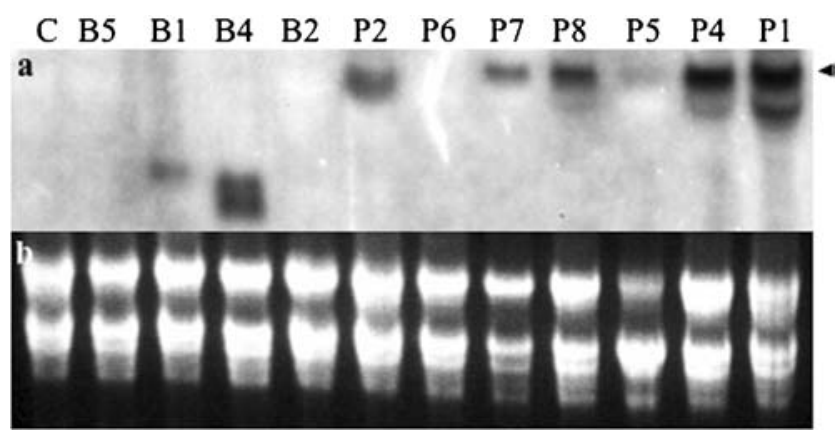

Fig. 5 Northern hybridisation analysis with GUS gene probe (a) and ribosomal RNA gel (b) of various transgenic regenerants classified as Low (L), Medium (M), and High (H) MU producers after fluorimetric GUS assay and cluster analysis. The arrowhead indicates the expected $1.8 \mathrm{~kb} G U S$ transcript. B1-B5 = biolistics-derived plants; $\mathrm{P} 1-\mathrm{P} 8=$ protoplast-derived plants. From left to right: $\mathrm{C}=$ Désirée control; $\mathrm{B} 5=\mathrm{B} 34-15 \mathrm{~A}(\mathrm{~L}) ; \mathrm{B} 1=\mathrm{B} 27-5 \mathrm{E}(\mathrm{L}) ; \mathrm{B} 4=\mathrm{B} 27-15 \mathrm{~B}(\mathrm{~L}) ; \mathrm{B} 2$ $=\mathrm{B} 34-12 \mathrm{~A}(\mathrm{~L}) ; \mathrm{P} 2=\mathrm{A} 2-01(\mathrm{~L}) ; \mathrm{P} 6=\mathrm{A} 1-51(\mathrm{~L}) ; \mathrm{P} 7=\mathrm{A} 2-05$ $(\mathrm{M}) ; \mathrm{P} 8=\mathrm{A} 2-04(\mathrm{M}) ; \mathrm{P} 5=\mathrm{A} 1-46(\mathrm{M}) ; \mathrm{P} 4=\mathrm{A} 1-17(\mathrm{H}) ; \mathrm{P} 1=$ A1-21 (H)

favourably to actual MU production levels except for line A1-46 (Fig. 5 lane 10), where an $\mathrm{RV}=20$ did not reflect the $256 \mathrm{pmoles} \mathrm{MU} / \mu \mathrm{g}$ protein/min typical of Medium cluster transformants; for example, Medium lines A2-05 $(\mathrm{RV}=40)$ and $\mathrm{A} 2-04(\mathrm{RV}=55)$ produced 199 and 220 pmoles MU/ $\mu \mathrm{g}$ protein/min, respectively. For com- pleteness, lines A1-17 $(\mathrm{RV}=80)$ and $\mathrm{A} 1-21(\mathrm{RV}=$

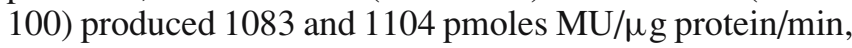
respectively.

Analyses of genomic DNA identified minor discrepancies for the number of insertion sites between the hybridisations of the two transgenes (Fig. 6). Except for two Low cluster plants, B34-15A and B27-5B (Fig. 6a and b, lanes 7 and 9), all plants exhibited multiple insertion sites, ranging from 2 to more than 10. Both High GUS expressing lines A1-17 and A1-21 had more than five individual inserts when probed with each gene (Fig. 6a and b, lanes 2 and 10), compared to the three Medium expressing lines which had fewer inserts. No correlation between insert number and GUS expression levels could be determined in our study since 2 of the Low cluster group had more than 10 GUS insertions sites each (Fig. 6a, lanes 5 and 12), and one had approximately 6 (Fig. 6a, lane 11).

Digestion of DNA to isolate the transgene cassettes did not result solely in single bands. All transformants examined produced the expected $1.8 \mathrm{~kb}$ fragment when probed with the $H P T$ gene (Fig. 6d), but four also produced larger, less intense fragments. When the same blot was probed with the (non-selected) GUS gene, only five of the transformants produced the expected $3.0 \mathrm{~kb}$ fragment. Not surprisingly, four of these turned out to be the selected Medium and High replicates. Low cluster line B27-15B (Fig. 6c, lane 5) produced at least two other bands as well as the
Fig. 6 Southern hybridisation analysis with GUS (a and $\mathbf{c}$ ) and $H P T$ gene probes (b and $\mathbf{d}$ ) of various transgenic regenerants classified as Low (L), Medium $(\mathrm{M})$, and High $(\mathrm{H}) \mathrm{MU}$ producers after fluorimetric GUS assay and cluster analysis. DNA for blot was cut either with EcoRI (a and b) or EcoRI-HindIII (c and d). Arrowheads indicate the expected fragment released after double digestion of genomic and plasmidic DNA. B1-B5 = biolistics-derived plants; P1-P8 $=$ protoplast-derived plants. From left to right: $\mathrm{C}=$ Désirée control; P4 = A1-17 (H); P5 = $\mathrm{A} 1-46(\mathrm{M}) ; \mathrm{P} 7=\mathrm{A} 2-05(\mathrm{M})$; $\mathrm{B} 4=\mathrm{B} 27-15 \mathrm{~B}(\mathrm{~L}) ; \mathrm{P} 8=\mathrm{A} 2-04$ (M); $\mathrm{B} 5=\mathrm{B} 34-15 \mathrm{~A}(\mathrm{~L})$; $\mathrm{P} 2=$ A2-01 (L); B1 = B27-5E (L); $\mathrm{P} 1=\mathrm{A} 1-21(\mathrm{H}) ; \mathrm{P} 6=\mathrm{A} 1-51$ (L); B2 = B34-12A (L); E = blank; $\mathrm{V}=\mathrm{p} G U S$-HYG control

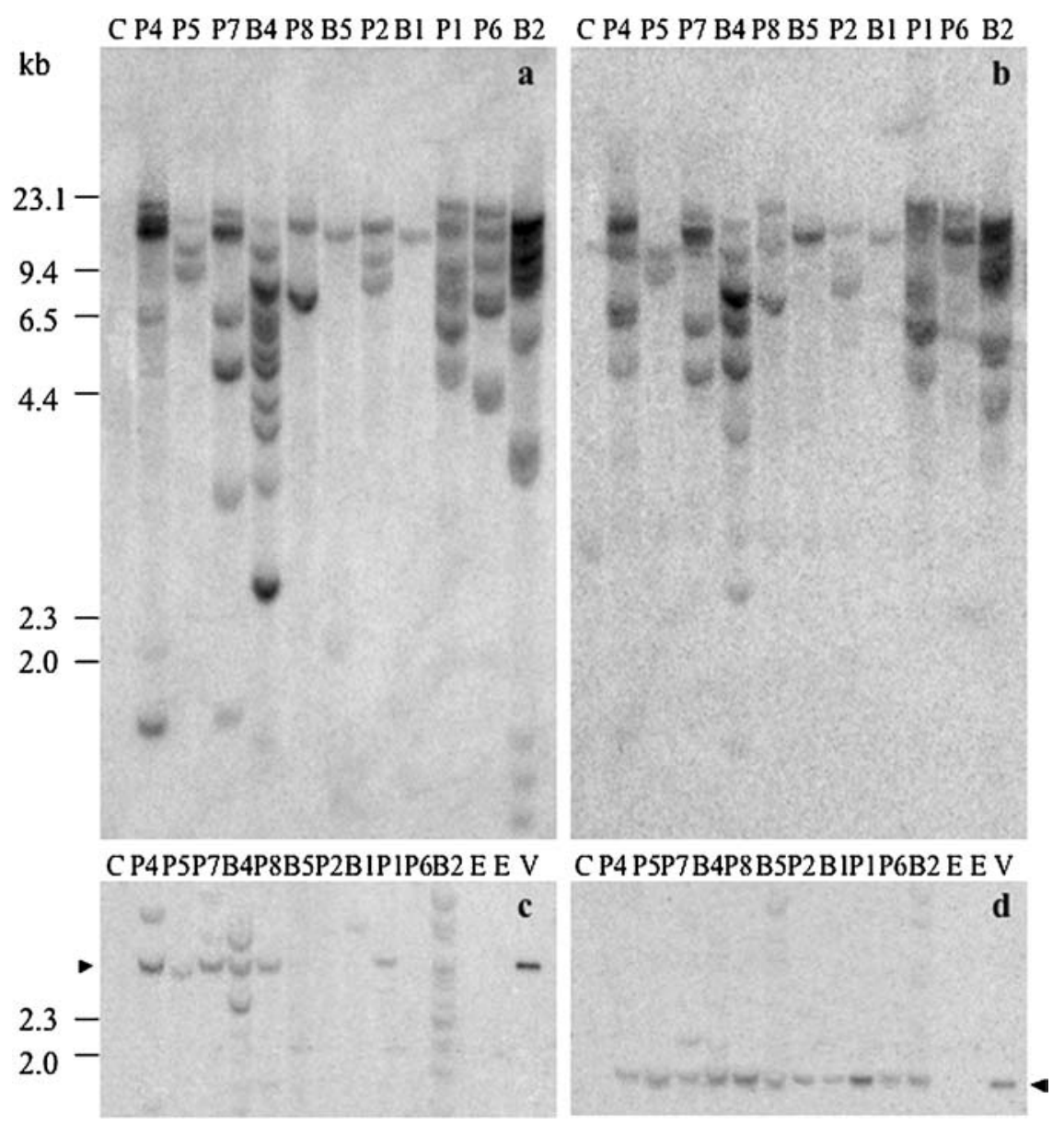


$3.0 \mathrm{~kb}$ fragment. Other lines also produced differentlysized fragments, for example, Low cluster lines B27-15B and B34-12A (Fig. 6c, lanes 5 and 12) produced more than 5 and 10 additional bands, repectively.

\section{Morphology of transgenic plants}

Approximately $30 \%$ of PD hyg ${ }^{\mathrm{r}}$ shoots exhibited somaclonal variation, as compared to $3-10 \%$ of $\mathrm{BD}$ shoots. Abnormal plants generally produced small, thick leaves, with a tendency towards laminar fusion of up to $50 \%$ of each leaf area (Fig. 2c and d).

\section{Discussion}

The results presented in this report demonstrate the improvement of direct DNA uptake in potato, resulting in transformation efficiencies higher than previously reported and transgene expression levels equivalent to those mediated by Agrobacterium transformation.

In biolistics experiments, our report of 0.5 and 1.8 hyg $^{\mathrm{r}}$ shoots per shot with protocols one and two, respectively, results in transformation efficiencies (T.E.) of 0.1 and 0.5 plants per leaf explant for the two protocols. In earlier experiments, Nguyen et al. (2002) obtained 0.5-0.6 hyg ${ }^{\mathrm{r}}$ shoots per shot (translating to 0.1-0.2 plants per leaf explant), while Romano et al. (2001) reported the production of $3 \mathrm{kan}^{\mathrm{r}}$ plants from a total of 157 leaf explants bombarded (T.E. $=0.02$ ). The higher transformation efficiency obtained in the present study may be due to a combination of factors, including the type of Gene Gun, bombardment and regeneration protocol, plant genotype, plasmid and selectable marker used.

For direct DNA uptake to protoplasts, when the data of Fehér et al. (1991) are converted to the number of $\operatorname{kan}^{\mathrm{r}}$ colonies obtained per million protoplasts treated, 152 colonies were obtained for the potato cv. Désirée. Our results with 20\% PEG were far lower (41 and 25, for equivalent replicates). However, when $12.5 \%$ PEG was used, the levels increased to 253 and 138 (extrapolated from Table 2), suggesting that by applying a more gentle PEG treatment (i.e. one of a lower concentration but of longer duration), higher numbers of resistant pcalli are capable of being produced. Once more, the higher number of antibiotic resistant Désirée pcalli obtained in the present study in comparison with Fehér et al. (1991) could be due to the different selection agent used (hygromycin versus kanamycin). Other notable deviations from the protocol of Fehér et al. (1991) were the addition of more plasmid DNA $\left(50 \mu \mathrm{g} \mathrm{m}^{-1}\right.$ as compared to $10 \mu \mathrm{g} \mathrm{ml}^{-1}$ ), and the non-denaturation of the carrier DNA. There was little difference in shoot regeneration frequencies between the different PEG treatments applied, with approximately $50 \%$ of hyg ${ }^{\mathrm{r}}$ pcalli producing multiple shoots during continued antibiotic selection. This differs significantly from Fehér et al. (1991), where regeneration was carried out under non-selective conditions and resulted in $60-80 \%$ of previously selected $\mathrm{kan}^{\mathrm{r}}$ cell colonies regenerating shoots.
When considering GUS activity levels in the transgenic population, those PD transformants which comprised the Medium and High clusters exhibited values (199$1121 \mathrm{pmoles} \mathrm{MU} / \mu \mathrm{g}$ protein/min) comparable to those from A. tumefaciens-transformed potato, for example, 460 $2000 \mathrm{pmoles} \mathrm{MU} / \mu \mathrm{g}$ protein/min (Ishida et al. 1989) and 218-1064 pmoles MU/ $\mu \mathrm{g}$ protein/min (values recalculated from published results; Park et al. 1995). In other studies, however, values similar to our Low cluster were reported (Wenzler et al. 1989; Romano et al. 2003).

In three Low category plants, truncated RNA transcripts were found. Aberrant GUS transcripts have also been reported in BD sorghum where they may be the product of a rearranged GUS gene or an in vivo degradation product of the larger correct GUS gene transcript (Hagio et al. 1991), and in two transgenic rice plants exhibiting GUS silencing where they were caused by a deletion located at the $5^{\prime}$ end of the GUS gene (Kohli et al. 1999). The rice transcripts also had questionable stability and detectability. The study indicated that cytosine methylation was involved in limited expression or silencing of the GUS gene in two other rice lines. Similar phenomena could be responsible for the reduction of, or lack of, GUS expression in lines produced in the present study.

Fragments of varying size and not identical to the respective gene cassettes were found in Southern blot analyses carried out to confirm transgene integrity. Larger fragments could be due to the integration of multiple copies of the transgenes as direct or inverted repeats (Kohli et al. 1998; Romano et al. 2003). They may also result from scrambling of non-contiguous transgene and genomic fragments recombined via illegitimate recombination (Svitashev et al. 2002; Romano et al. 2003), rearrangements which may be mediated in part by homologous recombination and synthesis-dependent mechanism(s) (Svitashev et al. 2002).

No transgene RNA was detected in two Low cluster plants with multiple transgene insertions. Multiple transgene copies can contribute to transgene silencing and inhibit transgene expression (Matzke et al. 1994). Additionally, very large transgenic loci can be meiotically unstable, leading to the loss of both loci and transgene expression in subsequent generations (Fu et al. 2000; and references therein). However, since several of our Medium and High category plants were also multicopy for both transgenes, silencing is clearly not an inevitable consequence of high copy number. In fact, rice lines containing multicopies of GUS and/or bar that could express the gene(s) stably at high levels up to the $\mathrm{R}_{3}$ generation have been reported (Kohli et al. 1999). Taken together, our Southern and northern analyses demonstrated the lack of correlation between gene copy and/or insertion site number with gene expression levels, a conclusion with growing consensus (Stoger et al. 1998; Kohli et al. 1999; Dai et al. 2001; Romano et al. 2003).

To our knowledge, no reports directly comparing DNA uptake in protoplasts with particle bombardment of explants are available. One study comparing two different protoplast-based transformation techniques found that donor DNA underwent structural changes and 
concatemerisations in protoplasts transformed by a DNA coprecipitation technique, while donor DNA integrated by cocultivation of protoplasts with Agrobacterium was often unaltered (Czernilofsky et al. 1986). Other studies comparing Agrobacterium- to biolistics-derived transgenic lines in cereals found transgene expression to be generally less stable in biolistics-derived lines (Dai et al. 2001; Travella et al. 2005) which were characterised as having more numerous, and mainly partial, transgene copies. These three studies imply that the specific treatment of donor DNA either prior to or during DNA uptake may affect the final integrity of the transgene DNA in situ, and thus its stability and expression to varying degrees in the subsequent transformant population.

The improved direct DNA uptake approaches reported in this study can both be used when the transfer of multiple genes is foreseen, as for the engineering of metabolic traits or the accumulation of recombinant products in potato (Romano et al. 2001, 2003, and references therein), or to improve available protocols for plastid transformation of this species (Sidorov et al. 1999; Gargano et al. 2003; Nguyen et al. 2005). However, at least for nuclear transformation, the outcome of the present gene expression analyses indicates that the protoplast approach is more successful at generating positive results and should be preferred when transgene expression level is an issue. In addition, in comparison with the biolistics approach, its cost is lower. On the other hand, it is a more difficult procedure, requiring specific technical expertise, and is often genotype-dependent. Finally, it should be considered that, as in the present study, the degree of somaclonal variation in plants regenerated from protoplasts is often reported to be higher than in tissue explant-derived plants (Ramulu 1987).

Acknowledgements We extend our heartfelt gratitude to A. Morgese and P. Palmieri for their excellent technical assistance. This work was partially funded by the European Union 5th Framework Programme, project “The Plastid Factory” (QLK3-CT-1999-00692). This article is contribution number 53 from the Institute of Plant Genetics, Research Division of Portici.

\section{References}

Cardi T, Puite KJ, Ramulu KS (1990) Plant regeneration from mesophyll protoplasts of Solanum commersonii Dun. Plant Sci 70:215-221

Cardi T, Bastia T, Monti L, Earle ED (1999) Organelle DNA and male fertility variation in Solanum spp. and interspecific somatic hybrids. Theor Appl Genet 99:819-828

Chen L, Marmey P, Taylor NJ, Brizard J-P, Espinoza C, D'Cruz P, Huet H, Zhang S, de Kochko A, Beachy RN, Fauquet CM (1998) Expression and inheritance of multiple transgenes in rice plants. Nature Biotechnol 16:1060-1064

Chomeczynski P, Sacchi N (1987) Single-step method of RNA isolation by acid guanidinium thiocyanate phenol chloroform extraction. Anal Biochem 162:156-159

Czernilofsky AP, Hain R, Herrera-Estrella L, Lorz H, Goyvaerts E, Baker BJ, Schell J (1986) Fate of selectable marker DNA integrated into the genome of Nicotiana tabacum. DNA 5:101-113

Dai S, Zheng P, Marmey P, Zhang S, Tian W, Chen S, Beachy RN, Fauquet C (2001) Comparative analysis of transgenic rice plants obtained by Agrobacterium-mediated transformation and particle bombardment. Mol Breed 7:25-33
Fehér A, Felföldi K, Preiszner J, Dudits D (1991) PEG-mediated transformation of leaf protoplasts of Solanum tuberosum L. cultivars. Plant Cell, Tiss \& Org Cult 27:105-114

Fu X, Duc LT, Fontana S, Bong BB, Tinjuangjun P, Sudhakar D, Twyman RM, Christou P, Kohli A (2000) Linear transgene constructs lacking vector backbone sequences generate lowcopy-number transgenic plants with simple integration patterns. Transgenic Res 9:11-19

Gargano D, Craig W, Lenzi P, Scotti N, Grillo S, Cardi T(2003) Stable plastid transformation of potato cv. Désirée with a gene involved in fatty acid desaturation. Proc. XLVII Ital. Soc. Agric. Genet.SIGA Annual Congress, Verona, Italy. 24-27 September 2003

Gamborg OL, Miller RA, Ojima K (1968) Nutrient requirements of suspension cultures of soybean root cells. Exp Cell Res 50:148-151

Haberlach GT, Cohen BA, Reichert NA, Baer MA, Towill LE, Helgeson P (1985) Isolation, culture and regeneration of protoplasts from potato and several related Solanum species. Plant Sci Lett 39:67-74

Hagio T, Blowers AD, Earle ED (1991) Stable transformation of sorghum cell cultures after bombardment with DNA-coated microprojectiles. Plant Cell Rep 10:260-264

Ishida BK, Snyder Jr GW, Belknap WR (1989) The use of in vitrogrown microtubers in Agrobacterium-mediated transformation of Russet Burbank and Lemhi Russet potatoes. Plant Cell Rep $8: 325-328$

Jefferson RA, Kavanagh TA, Bevan MW (1987) GUS fusions: beta-glucuronidase as a sensitive and versatile gene fusion marker in higher plants. EMBO J 6:3901-3907

Kohli A, Leech M, Vain P, Laurie DA, Christou P (1998) Transgene organisation in rice engineered through direct DNA transfer supports a two-phase integration mechanism mediated by the establishment of integration hot spots. Proc Natl Acad Sci USA 95:7203-7208

Kohli A, Gahakwa D, Vain P, Laurie DA, Christou P (1999) Transgene expression in rice engineered through particle bombardment: Molecular factors controlling stable expression and transgene silencing. Planta 208:88-97

Maliga P (1995) Biolistic transformation of tobacco cells with nuclear drug resistance genes. In: Maliga $\mathrm{P}$, Klessig DF, Cashmore AR, Gruissem W, Varner JE (eds) Methods in Plant Molecular Biology: A Laboratory Course Manual. Cold Spring Harbor Press, Cold Spring Harbor, New York, pp $37-$ 54

Matzke AJM, Neuhuber F, Park YD, Ambros PF, Matzke MA (1994) Homology-dependent gene silencing in transgenic plants: Epistatic silencing loci contain multiple copies of methylated transgenes. Mol Gen Genet 244:219-229

McGill R, Tukey JW, Larsen WA (1978) Variations of box plots. Amer Statistician 32:12-16

Murashige T, Skoog F (1962) A revised medium for rapid growth and bioassays with tobacco tissue cultures. Physiol Plant $15: 473-497$

Negrutiu I, Shillito R, Potrykus I, Biasini G, Sala F (1987) Hybrid genes in the analysis of transformation conditions. I. Setting up a simple method for direct gene transfer in plant protoplasts. Plant Mol Biol 8:363-373

Nguyen TT, Nugent G, Dix P (2002) Biolistic transformation of potato (Solanum tuberosum L.) In: 10th IAPTC\&B Congress, Plant Biotechnology 2002 and Beyond, A Celebration and a Showcase, Book of Abstracts, poster number P-1373, p 127-A

Nguyen TT, Nugent G, Cardi T, Dix P (2005) Generation of homoplasmic plastid transformants of a commercial cultivar of potato (Solanum tuberosum L.) Plant Sci, 168:1495-1500

Park YD, Ronis DH, Lorenzen JH (1995) Suppression of marker genes in sequentially transformed potato (Solanum tuberosum L.) Am Pot J 72:599-604

Ramulu KS (1987) Genetic instability during plant regeneration in potato: Origin and implications. Plant Physiol (Life Sci Adv) 6:211-218 
Romano A, Raemakers K, Visser R, Mooibroek H (2001) Transformation of potato (Solanum tuberosum) using particle bombardment. Plant Cell Rep 20:198-204

Romano A, Raemakers K, Bernardi J, Visser R, Mooibroek $\mathrm{H}$ (2003) Transgene organisation in potato after particle bombardment-mediated (co-)transformation using plasmids and gene cassettes. Transgenic Res 12:461-473

Sambrook J, Russell DW (2001) Molecular cloning: A laboratory manual, 3rd ed. Cold Spring Harbor Laboratory Press, New York

Sidorov VA, Kasten D, Pang S-Z, Hajdukiewicz PTJ, Staub JM, Nehra NS (1999) Stable chloroplast transformation in potato: Use of green fluorescent protein as a plastid marker. Plant $\mathbf{J}$ 19:209-216

Stoger E, Williams S, Keen D, Christou P (1998) Molecular characteristics of transgenic wheat and the effect on transgene expression. Transgenic Res 7:463-471

Svitashev SK, Pawlowski WP, Makarevitch I, Plank DW, Somers DA (2002) Complex transgene locus structures implicate multiple mechanisms for plant transgene rearrangement. Plant J 32:433-445
Travella S, Ross SM, Harden J, Everett C, Snape JW, Harwood WA (2005) A comparison of transgenic barley lines produced by particle bombardment and Agrobacterium-mediated techniques. Plant Cell Rep 23:780-789

Vieira MLC, Jones B, Cocking EC, Davey MR (1990) Plant regeneration from protoplasts isolated from seedling coytledons of Stylosanthes guianensis, S. macrocephala and S. scabra. Plant Cell Rep 9:289-292

Wenzler H, Mignery G, May G, Park W (1989) A rapid and efficient transformation method for the production of large numbers of transgenic potato plants. Plant Sci 63:79-85

Yadav NR, Sticklen MB (1995) Direct and efficient regeneration from leaf explants of Solanum tuberosum L. cv. Bintje. Plant Cell Rep 14:645-647 